\title{
Trophodynamics of anchovy in a non-upwelling system: direct comparison with sardine
}

\author{
N. Nikolioudakis*, S. Isari, S. Somarakis \\ Institute of Marine Biological Resources and Inland Waters, Hellenic Centre for Marine Research, Thalassocosmos, \\ Heraklion 71003, Crete, Greece
}

\begin{abstract}
Anchovies and sardines hold a very important position in pelagic ecosystems and are usually found in species pairs, exhibiting fluctuations in abundance. In upwelling systems, alternations in small pelagic fish have been hypothesized to be, at least partly, trophically mediated. In non-upwelling areas, direct comparisons of sardine and anchovy trophodynamics are lacking, which represents an impediment to our understanding of forage fish interactions. In the present study, we analyzed the diel feeding periodicity, daily ration and diet composition of anchovy Engraulis encrasicolus in a coastal area of the eastern Mediterranean. The anchovy feeding parameters and diet compositions were then compared with published data on sardine Sardina pilchardus, captured in the same set of pelagic trawl hauls and analyzed using identical methods. Both anchovy and sardine foraged in daytime in summer, and mainly at night in winter. Their feeding intensities per daily sampling time were highly correlated. In both species, daily consumption was significantly and similarly related to fish size and per capita food availability. In terms of dietary carbon, intraspecific dietary differences between juveniles and adults were insignificant. Copepods (especially large ones) were the main energy source for both species. In contrast to adult sardines, anchovies did not consume phytoplankton, and ingested large prey (including decapod larvae) more frequently. Both species broadened their trophic niche in summer; dietary differences between the stratification and mixing periods mostly reflected corresponding changes in prey availability in the field. The strong size-based partitioning of plankton resources described for anchovy and sardine in upwelling systems was not corroborated in the Mediterranean Sea.
\end{abstract}

KEY WORDS: Diet · Daily ration · Trophic ecology $\cdot$ Small pelagic fish $\cdot$ Mediterranean Sea Resale or republication not permitted without written consent of the publisher

\section{INTRODUCTION}

Small pelagic fish (SPF) play an important role in marine food webs as they are the principal means of energy transfer from plankton to larger predatory fish, and to marine mammals and seabirds (Cury et al. 2000, Pikitch et al. 2014). They are highly abundant, especially in upwelling systems, which has been attributed to their dietary plasticity and ability to efficiently exploit the planktonic food web (van der Lingen et al. 2009). SPF are omnivorous planktivores, able to switch between filter- and particulate feeding modes (James 1987, van der Lingen et al. 2006, Garrido et al. 2007), and they derive the bulk of their dietary carbon from zooplankton, mainly copepods and euphasuiids (e.g. Garrido et al. 2008, Espinoza \& Bertrand 2008, Espinoza et al. 2009, van der Lingen et al. 2009, Nikolioudakis et al. 2012).

Anchovies and sardines are usually found as species pairs in both upwelling (Checkley et al. 2009) and non-upwelling systems (Alheit et al. 2009). When occurring in the same system, their biomasses usually fluctuate in decadal and centennial style, which is often associated with ecosystem regime 
shifts governed by physical processes (Alheit et al. 2009, Gutiérrez et al. 2009). However, long periods of coexistence of the 2 species have also been reported in paleo-studies in upwelling areas such as the California and Humboldt Current systems (Field et al. 2009). The short life span, high fecundities and trophic dependence of SPF on plankton-based food chains enable them to respond rapidly to changes in ocean forcing (Alheit et al. 2009).

Van der Lingen et al. (2006) hypothesized that the size structure of zooplankton as determined by the prevailing hydrological conditions, and the differences in trophic ecology between anchovy and sardine could regulate the biomass alternations of the 2 species in the Benguela Current system. More specifically, anchovies use the particulate-feeding mode more efficiently, and their feeding apparatus is better designed to capture large zooplankton that thrive in upwelling conditions (van der Lingen et al. 2006). In contrast, sardines benefit from using the filter-feeding mode, as their finer branchial basket allows them to retain smaller zooplankton that are abundant in stable water column conditions (van der Lingen et al. 2006).

The trophic ecology of sardine and anchovy has been studied thoroughly in upwelling systems both in field and experimental conditions (van der Lingen et al. 2009 and references therein). In non-upwelling areas, related studies have increased in recent years (e.g. Tudela \& Palomera 1997, Plounevez \& Champalbert 1999, Bacha \& Amara 2009, Borme et al. 2009, Nikolioudakis et al. 2011, 2012, Costalago et al. 2012); however, direct comparisons of anchovy and sardine trophodynamics are lacking for these areas. Costalago et al. (2012) is the only study providing comparative dietary data, but these were derived from isotopic values rather than direct prey composition analysis, and thus did not provide detailed information on prey items at the species level.

In the present study, we investigated the trophodynamics of anchovy Engraulis encrasicolus in an eastern Mediterranean coastal ecosystem. We analyzed the species' diel feeding periodicity, daily ration and diet composition in different seasons and ontogenetic stages (juveniles and adults). The trophic parameters and prey compositions of anchovy were then compared with those published for sardine Sardina pilchardus (Nikolioudakis et al. 2011, 2012) in an effort to identify similarities and differences in their trophic ecology. Inter-specific comparisons were straightforward since samples of the 2 species were collected in the same set of pelagic trawl hauls and identical methods were followed in the analyses.

\section{MATERIALS AND METHODS}

To assess anchovy trophodynamics, we employed the same methodology applied to European sardine described in Nikolioudakis et al. $(2011,2012)$. Hence, a brief outline of methods is only given here and the reader is referred to the aforementioned papers for more detailed descriptions.

\section{Sampling}

Sampling was carried out during 2 periods: (1) a period of thermal stratification (July 2007 [S07] and July 2008 [S08]; hereafter also referred to as 'summer') and (2) a period of mixing (December 2007 [W07] and February 2009 [W09]; 'winter') in a coastal area of the North Aegean Sea (eastern Mediterranean) with increased abundance of small pelagic fish (Nikolioudakis et al. 2011). Pelagic trawl hauls were carried out at different times during consecutive days to cover the entire $24 \mathrm{~h}$ cycle in each of the 4 sampling periods (SP) (see Fig. S1 in the Supplement at www.int-res.com/articles/suppl/m500p215_supp.pdf). Once onboard, fish were sorted into 4 size classes (35 to $80 \mathrm{~mm}, 81$ to $100 \mathrm{~mm}, 101$ to $120 \mathrm{~mm}$ and $>120 \mathrm{~mm}$ total length). At least 2 batches of 20 anchovies per size class (when available) were immediately stored at $-35^{\circ} \mathrm{C}$.

Components of the abiotic and planktonic environment were also sampled at 3 stations covering the average trawling path in each SP (Nikolioudakis et al. 2012). Vertical profiles of temperature and salinity, plankton-net samples (to measure the composition and biomass of mesozooplankton and microplankton) and depth-stratified water samples (for dissolved inorganic nutrients, chlorophyll $a$, picoand nanoplankton, phytoplankton and ciliates) were collected at each station (Nikolioudakis et al. 2012).

\section{Laboratory analysis}

In the laboratory, anchovies were thawed, and the following parameters were recorded for each fish: total length (TL), total weight (TW), eviscerated weight (EW), sex (Sex), presence of yolked or hydrated oocytes (microscopic examination of ovaries) and gonad weight (GW). A sample of 20 fish (when available) per size class (Size) and SP was used for the feeding periodicity and the daily ration (DR, hereafter also referred to as consumption, C) analysis. The dry weight (DW) of the stomach contents was 
determined. For the description of diet, the other sample of 20 fish (when available) per Size and SP collected during the day, at sunset and at night were examined to thoroughly cover the daily cycle. For each sample, prey were removed from the stomachs, stored in $4 \%$ borax-buffered formaldehyde solution and identified to the lowest possible taxonomic level, after pooling the stomach contents of each batch of fish (Nikolioudakis et al. 2012). Unidentifiable material (present only to a minor extent in a few of the stomachs examined) was not taken into account. Stereomicroscopy and inverted microscopy on appropriate aliquots were used for prey $>200 \mu \mathrm{m}$ and $<200 \mu \mathrm{m}$, respectively. Appropriate measurements on 30 randomly selected individuals (when available) from each identified taxon were taken for size-tocarbon conversions and for recording the length of each prey (Nikolioudakis et al. 2012).

\section{Data analysis}

Ovaries of anchovies caught in summer were examined under a stereoscope, and individuals were classified as mature (presence of yolked and/or hydrated oocytes) or immature (non yolked/hydrated oocytes). The length-at-maturity $\left(L_{50}\right)$ was determined by fitting a logistic regression on the relationship between the percentages (P) of mature fish at (total) length class $L$ (Somarakis et al. 2006). The resulting $L_{50}$ was $99.92 \mathrm{~mm}$ (95\% CI: 98.19 to 101.60, $\mathrm{r}^{2}=0.91$ ) and the length threshold of $100 \mathrm{~mm}$ was therefore used to assign individuals to ontogenetic stage: fish $<100 \mathrm{~mm}$ were labeled as 'juveniles' and fish $\geq 100 \mathrm{~mm}$ as 'adults'.

The average catch per unit effort (CPUE) of anchovy (catch per haul duration; $\mathrm{kg} \mathrm{h}^{-1}$ ) in the hauls that had been carried out during the night was calculated as an index of anchovy density in the sampling area (Nikolioudakis et al. 2011). The ratio of mesozooplankton biomass to anchovy CPUE, i.e. $B_{R}=$ $\log _{\mathrm{e}}$ (mesozooplankton biomass / CPUE) was an index of per capita food availability (Nikolioudakis et al. 2011).

\section{Daily ration and feeding periodicity}

The daily ration and feeding periodicity of anchovy were investigated based on 52 positive hauls (see Fig. S1 in the Supplement). In each SP, samples from different dates were pooled and assigned to 8 consecutive $3 \mathrm{~h}$ intervals representing an entire diel cycle (i.e. $23: 00 \mathrm{~h}$ to $02: 00 \mathrm{~h}, 02: 00 \mathrm{~h}$ to $05: 00 \mathrm{~h}, \ldots$, 20:00 h to 23:00 h). In total, 1698 stomachs were used, excluding the few (33) completely empty stomachs encountered. Stomach content DW was used to estimate feeding intensity after adjusting for fish size with generalized linear models (GLMs). The rationale for adopting the GLM approach is described in Nikolioudakis et al. (2011). Estimated marginal means of DW (fixed at mean EW) for each SP and sampling time (Time), were used as inputs to the Elliott \& Persson (E-P) (Elliott \& Persson 1978) and the Eggers (Eggers 1979) consumption models. The instantaneous gastric evacuation rate $\left(\mathrm{R}_{\max }\right)$ was estimated as recommended in Héroux \& Magnan (1996). To facilitate comparisons with other studies, daily ration was also calculated as a fraction of total wet weight (\%TW) by converting DW to wet weight (Nikolioudakis et al. 2011).

\section{Diet}

In total, 30 samples (S07: 6, W07: 9, S08: 6 and W09: 9) of 20 fish each (when available) were used to study the diet composition of anchovy. The specific selection of anchovies for a given prey was quantified using Ivlev's selectivity index (Ivlev 1961). The chisquare test $\left(\chi^{2}\right)$ was employed to compare the sizefrequency distributions of prey between juveniles and adults in each SP. Hierarchical agglomerative clustering and multidimensional scaling (MDS) ordination (Clarke \& Warwick 1994) on Bray-Curtis similarity matrices of the numeric (\%n) and carbon content $(\% \mathrm{C})$ diet composition data were performed to detect groups of samples with similar diet compositions. The SIMPER routine (Clarke \& Warwick 1994) was utilized to identify the taxa that contributed to the dietary differences between groups. PERMANOVA tests allowed for the detection of statistically significant differences (Anderson et al. 2008). Diet overlap was quantified using Schoener's formula (Schoener 1970). For each SP, the size-frequency distributions in terms of $\% \mathrm{n}$ and $\% \mathrm{C}$ were calculated for all prey found in the stomachs as well as only for the (combined) copepod and cladoceran groups. These groups dominated the mesozooplankton community during all SPs (Nikolioudakis et al. 2012) and they were always present in the stomachs of fish, contributing $>1 \%$ to the dietary carbon. Additionally, size-frequency distributions of copepods and cladocerans were constructed for field-collected mesozooplankton (Nikolioudakis et al. 2012) since copepods and cladocerans are quantitatively sampled by verti- 
cal WP2-net tows (Skjoldal et al. 2013). The weighted mean length $\left(\right.$ size $_{\text {diet }}$ ) of ingested copepods and cladocerans in each SP was calculated (Nikolioudakis et al. 2012) and then related to the respective mean size in the field (size field $_{\text {). }}$.

To simplify presentations, the comparisons of sardine and anchovy diets were restricted to adult fish. Sardine juveniles $(<100 \mathrm{~mm})$ were only collected during summer (July 2007 and July 2008) and their diet did not differ from that of adults in terms of dietary carbon or mesozooplankton prey sizes (Nikolioudakis et al. 2012). Differences were not found between juvenile and adult anchovy in the present study either (see 'Results').

\section{RESULTS}

\section{Diel feeding periodicity and daily ration}

The final GLMs describing the feeding intensity of juveniles $(<100 \mathrm{~mm})$ and adults $(\geq 100 \mathrm{~mm})$ explained $\sim 66 \%$ and $\sim 61 \%$ of the deviance, respectively (Table 1). In both cases, Time was the predictor that explained the largest proportion of deviance $(\sim 25 \%$ for juveniles and $\sim 36 \%$ for adults). Significant interactions of SP and Time with fish EW were interpretable in terms of changing slopes of the DW-EW relationship between cruises and sampling times (Ni-

Table 1. Engraulis encrasicolus. Analysis of deviance table for the gammabased generalized linear model fitted to stomach content dry weight. $\mathrm{df}=$ degrees of freedom; $\mathrm{SP}=$ sampling period; Time $=$ sampling time; $\mathrm{EW}=$ eviscerated weight; ${ }^{* *} \mathrm{p}<0.001 ;{ }^{* * *} \mathrm{p}<0.0001$

\begin{tabular}{|c|c|c|c|c|c|c|}
\hline $\begin{array}{l}\text { Source of } \\
\text { variation }\end{array}$ & df & Deviance & $\begin{array}{c}\text { Explained } \\
\text { deviance (\%) }\end{array}$ & $\begin{array}{l}\text { Residual } \\
\text { df }\end{array}$ & $\begin{array}{l}\text { Residual } \\
\text { deviance }\end{array}$ & $\begin{array}{c}\mathrm{p}- \\
\text { value }\end{array}$ \\
\hline \multicolumn{7}{|l|}{ Juveniles } \\
\hline Null & & & & 1268 & 902.34 & \\
\hline $\mathrm{SP}$ & 3 & 175.76 & 19.48 & 1265 & 726.58 & $* * *$ \\
\hline Time & 7 & 224.05 & 24.83 & 1258 & 502.53 & $* * *$ \\
\hline EW & 1 & 74.33 & 8.24 & 1257 & 428.20 & $* * *$ \\
\hline SP $\times$ Time & 21 & 105.02 & 11.64 & 1236 & 323.19 & $* * *$ \\
\hline Time $\times$ EW & 7 & 4.05 & 0.45 & 1229 & 319.14 & $* *$ \\
\hline $\mathrm{SP} \times \mathrm{EW}$ & 3 & 2.88 & 0.32 & 1226 & 316.26 & $* *$ \\
\hline $\begin{array}{l}\text { SP } \times E W \times \text { Time } \\
\text { Total }\end{array}$ & 20 & 13.33 & $\begin{array}{r}1.48 \\
66.43\end{array}$ & 1206 & 302.93 & $* * *$ \\
\hline \multicolumn{7}{|l|}{ Adults } \\
\hline Null & & & & 1191 & 702.58 & \\
\hline SP & 3 & 55.44 & 7.89 & 1188 & 647.14 & $* * *$ \\
\hline Time & 7 & 252.96 & 36.01 & 1181 & 394.17 & $* * *$ \\
\hline EW & 1 & 12.08 & 1.72 & 1180 & 382.10 & $* * *$ \\
\hline $\mathrm{SP} \times$ Time & 21 & 103.57 & 14.74 & 1159 & 278.53 & $* * *$ \\
\hline $\mathrm{SP} \times \mathrm{EW}$ & 3 & 4.19 & 0.60 & 1152 & 274.34 & $* *$ \\
\hline Total & & & 60.95 & & & \\
\hline
\end{tabular}

kolioudakis et al. 2011). With regard to adults, terms including Sex were not significant. The estimated marginal means with $95 \%$ confidence intervals for the multiplicative effect of SP $\times$ Time are shown in Fig. 1, with EW fixed at $3.18 \mathrm{~g}$ for juveniles and $8.36 \mathrm{~g}$ for adults. Both juvenile and adult anchovies presented a clear daytime feeding pattern in summer (Fig. 1). Stomachs were almost empty at around sunrise, progressively reaching a peak in fullness near sunset, when prey items were almost intact (Fig. 1). After the sunset peak, feeding ceased (as the absence of freshly ingested prey implied) resulting in a noticeable drop in stomach content DW. In the mixing periods (winter), feeding occurred throughout the day, peaked in the early night, and ceased after midnight (Fig. 1).

Comparing these results with those of sardine (Nikolioudakis et al. 2011), the diel feeding patterns of the 2 species were very similar in all SPs. The GLM adjusted mean stomach contents DWs of anchovy per sampling time were closely correlated with those of sardine for the same SP and ontogenetic stage (adults [S07: $\mathrm{r}=0.951$, W07: $\mathrm{r}=0.716$, S08: $\mathrm{r}=0.975$, W09: $\mathrm{r}=$ 0.948]; juveniles [S07: $\mathrm{r}=0.906$ ]) (Fig. 2).

There was little difference in the estimated $R_{\max }$ of juvenile and adult anchovy between July 2007 and July 2008 or between December 2007 and February 2008 (Table 2). $\mathrm{R}$ values were lower in winter than in summer. A significant relationship existed between $\mathrm{R}$ and surface $(5 \mathrm{~m})$ temperature $(T)(\mathrm{R}=$ $0.069 \times \mathrm{e}^{0.068 \times T} ; \mathrm{n}=8, \mathrm{r}^{2}=0.988, \mathrm{p}<$ 0.0001). Estimates of consumption by the E-P models (Table 2) were highly correlated $(r=0.986, p<0.001)$. DR of juveniles was higher than that of adults in all studied periods in terms of $\%$ TW (Table 2). Furthermore, DR was higher in summer than in winter for both juveniles and adults (Table 2).

The ratio of mesozooplankton biomass to anchovy CPUE, i.e. $B_{R}=$ $\log _{\mathrm{e}}$ (mesozooplankton biomass/CPUE) was related to DR: when the size class factor (juveniles or adults) was taken into account, the daily ration according to the E-P model, $\mathrm{C}_{\mathrm{E}-\mathrm{P}}(\% \mathrm{TW})$, was significantly and linearly correlated to $\mathrm{B}_{\mathrm{R}}\left(F=35.35, \mathrm{p}=0.001\right.$, adj. $\left.\mathrm{r}^{2}=0.908\right)$. The mean weight of juveniles and adults (juveniles: $3.18 \mathrm{~g}$ TW, adults: $8.36 \mathrm{~g} \mathrm{TW}$ ) entered into the $\mathrm{C}_{\mathrm{E}-\mathrm{P}}$-on- $\mathrm{B}_{\mathrm{R}}$ regression as a significant covariate (Fig. 3A), indicating that, if a linear 

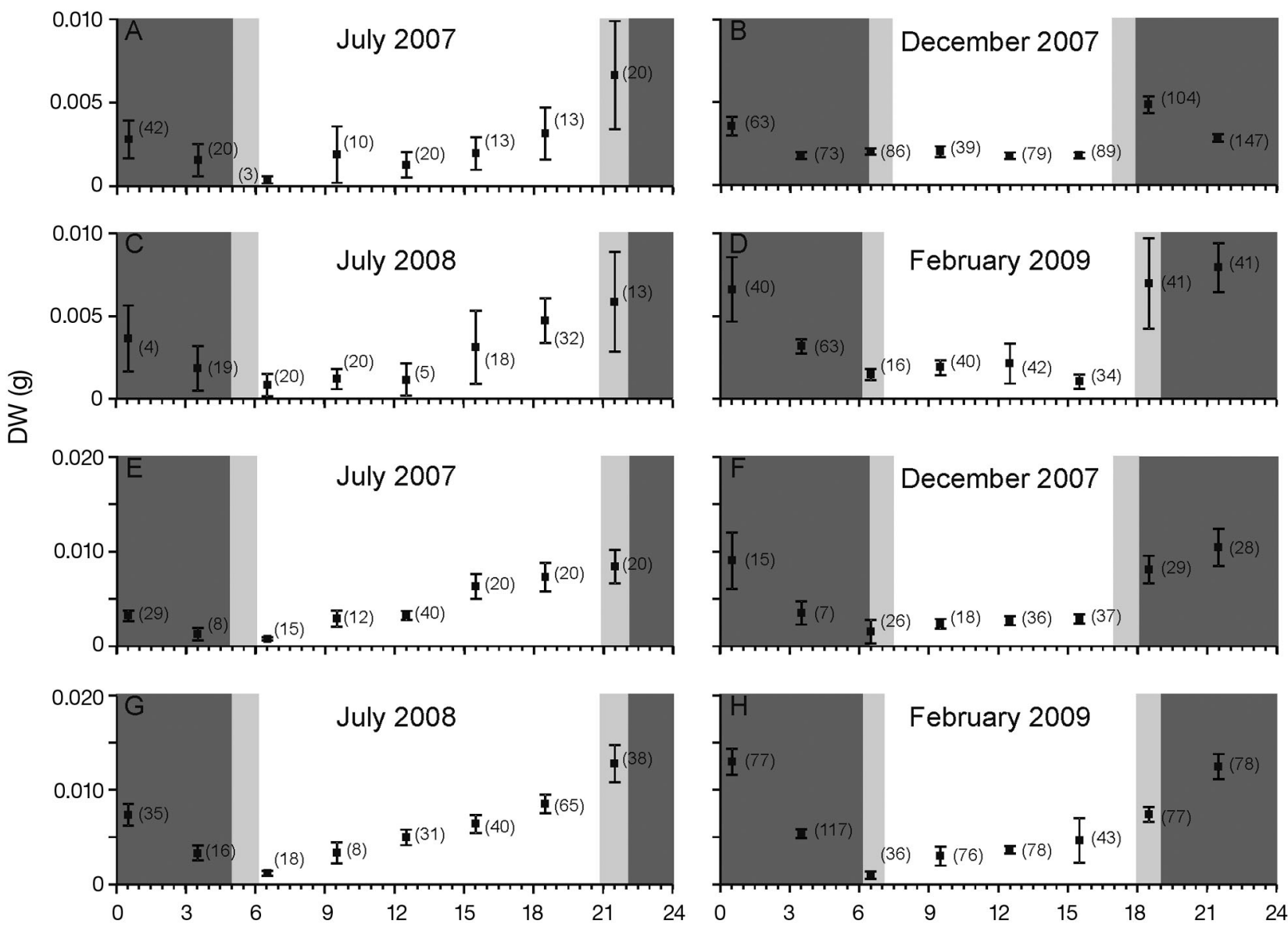

Time (h)

Fig. 1. Engraulis encrasicolus. Estimated marginal means of stomach content dry weight (DW, g), with $95 \%$ confidence intervals for (A-D) juvenile and (E-H) adult anchovy. Nautical twilight (light grey bar) and nighttime (dark grey bar) are also shown in each graph. Note the different scale on the $y$-axis between juveniles and adults. Numbers of fish stomachs excised in each sampling period are shown in parentheses

decrease in food consumption with fish size is assumed, consumption in terms of \% TW decreases by a factor of 0.179 per gram increase in TW.

When the $C_{E-P}$ to $B_{R}$ relationship was examined for both anchovy and sardine, a similar relationship was found, and the factor Species did not enter significantly into the multiple regression model $(p=0.32)$ (Fig. 3B). Additionally, when the consumption of one species was regressed against the $B_{R}$ of the other species, the latter did not enter the model as a significant term $(p=0.868)$, indicating no inter-specific, but high intra-specific competition in food consumption.

\section{Diet composition}

In total, 589 stomachs of anchovies were analyzed, and 29 taxa were identified belonging to 7 prey groups (see Table S1 in the Supplement at www.intres.com/articles/suppl/m500p215_supp.pdf). Mean prey numbers in the stomachs ranged from 101 to 1516 items. Juveniles and adults preyed almost exclusively on copepods in all SPs, regardless of whether prey compositions were calculated in terms of $\% \mathrm{n}$ or $\% \mathrm{C}$ (Fig. 4, Table S1). In terms of \%n, the copepods Acartia clausi, Oncaea spp., Euterpina acutifrons and Temora stylifera were the main prey in summer. Centropages spp. were the dominant food item in winter, followed by Pontellidae and Clauso-Paracalanidae (Table S1). In terms of \% $\mathrm{C}$, larger prey contributed the most to the diet, namely A. clausi and T. stylifera in summer and Centropages spp. in winter (Table S1). Other prey groups (e.g. gastropods, decapods, cladocerans and bivalves) were also part of the diet mainly during the stratification periods (Fig. 4, Table S1). Phytoplankton cell numbers were negligible, usually 


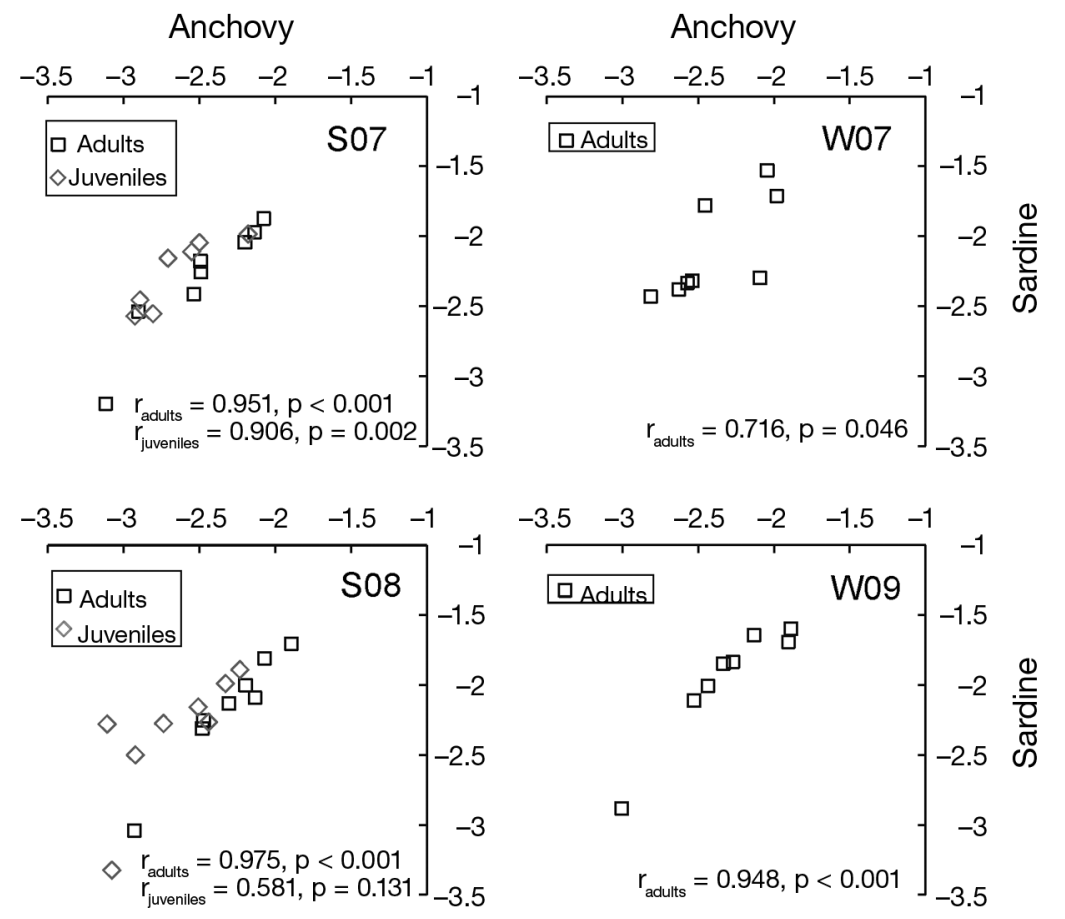

Fig. 2. Engraulis encrasicolus and Sardina pilchardus. Pearson-correlation coefficients between anchovy and sardine stomach content dry weight (DW, g), at each sampling time, for juveniles (grey diamonds, $r_{\text {juveniles }}$ ) and adults (black squares, $r_{\text {adults }}$ ). Data for sardine were published in Nikolioudakis et al. (2011) and derived from the same set of pelagic trawl hauls

Table 2. Engraulis encrasicolus. Estimates of gastric evacuation $\left(\mathrm{h}^{-1}\right)$ and consumption rates $\left(\mathrm{DW} \mathrm{d}^{-1}\right)$. Consumption values are also expressed as percent total weight $(\% \mathrm{TW}) . \mathrm{R}_{\max }=$ gastric evacuation rate; $\mathrm{DW}=$ dry weight (standardized mean stomach content); $\mathrm{C}_{\mathrm{E}-\mathrm{P}}=$ daily ration according to the ElliottPersson model $\mathrm{C}_{\mathrm{E}}=$ daily ration according to the Eggers model

\begin{tabular}{|lcccccc|}
\hline $\begin{array}{l}\text { Sampling } \\
\text { period }\end{array}$ & $\begin{array}{c}\mathrm{R}_{\max } \\
( \pm \mathrm{SE})\end{array}$ & $\mathrm{DW}$ & $\begin{array}{c}\mathrm{C}_{\mathrm{E}-\mathrm{P}} \\
( \pm \mathrm{SE})\end{array}$ & $\begin{array}{c}\mathrm{C}_{\mathrm{E}-\mathrm{P}} \\
(\% \mathrm{TW})\end{array}$ & $\mathrm{C}_{\mathrm{E}}$ & $\begin{array}{c}\mathrm{C}_{\mathrm{E}} \\
(\% \mathrm{TW})\end{array}$ \\
\hline $\begin{array}{l}\text { Juveniles } \\
\text { Jul 2007 }\end{array}$ & $0.389(0.054)$ & 0.0024 & $0.0200(0.0041)$ & 4.38 & 0.0205 & 4.50 \\
Dec 2007 & $0.189(0.038)$ & 0.0027 & $0.0106(0.0010)$ & 2.33 & 0.0084 & 1.84 \\
Jul 2008 & $0.402(0.085)$ & 0.0028 & $0.0215(0.0102)$ & 4.71 & 0.0216 & 4.74 \\
Feb 2009 & $0.138(0.070)$ & 0.0044 & $0.0177(0.0041)$ & 3.87 & 0.0114 & 3.54 \\
Adults & & & & & & \\
Jul 2007 & $0.364(0.080)$ & 0.0048 & $0.0350(0.0039)$ & 2.92 & 0.0340 & 2.83 \\
Dec 2007 & $0.180(0.052)$ & 0.0071 & $0.0157(0.0025)$ & 1.50 & 0.0152 & 1.56 \\
Jul 2008 & $0.423(0.068)$ & 0.0062 & $0.0515(0.0042)$ & 4.30 & 0.0510 & 4.25 \\
Feb 2009 & $0.135(0.060)$ & 0.0067 & $0.0260(0.0016)$ & 2.30 & 0.0264 & 2.28 \\
\hline
\end{tabular}

$<3$ cells per stomach, and hence were not considered as a prey item, as they were not a targeted prey but only incidentally ingested.

The analysis of prey selectivity (E) showed that many prey were positively and heavily selected by both juveniles and adults (e.g. Euterpina acutifrons in summer and Oncaea spp. in both summer and

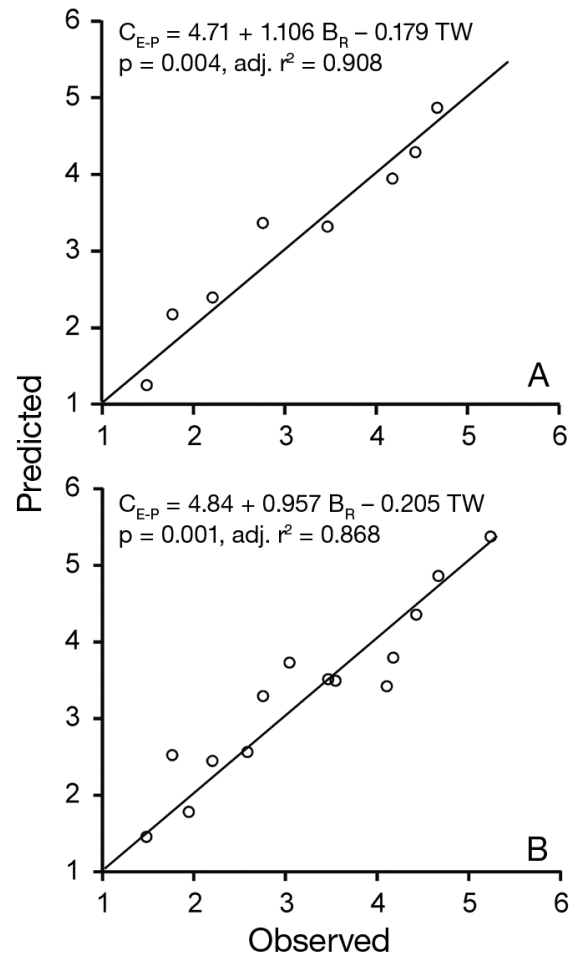

Fig. 3. Engraulis encrasicolus and Sardina pilchardus. Observed versus predicted values of the multiple regression of consumption $\left(\mathrm{C}_{\mathrm{E}-\mathrm{P}}, \% \mathrm{TW}\right)$ versus $\log _{\mathrm{e}}$ (mesozooplankton biomass/catch per unit effort) $\left(B_{R}\right)$ and fish mean total weight (TW) for (A) anchovy only and (B) for anchovy and sardine (pooled analysis). Data for sardine were published in Nikolioudakis et al. (2011) and were derived from the same set of pelagic trawl hauls

winter) (Table 3). However, negative selectivity values were calculated for taxa such as the cladoceran Penilia avirostris in summer or the ClausoParacalanidae group in both summer and winter, implying avoidance and/ or low catchability of these prey species by anchovy (Table 3). Finally, in certain cases, taxa with low abundance in the field such as Microsetella rosea and Candacia spp. were positively selected by anchovy (Table 3 ).

The diet of anchovies in each SP exhibited medium to high overlap between juvenile and adult stages as revealed by Schoener's index (Table 4). This was also confirmed by the medium to high average similarities for the 2 stages in the SIMPER analyses (Table S2 in the Supplement). The 2-way PERMANOVA test showed that neither 


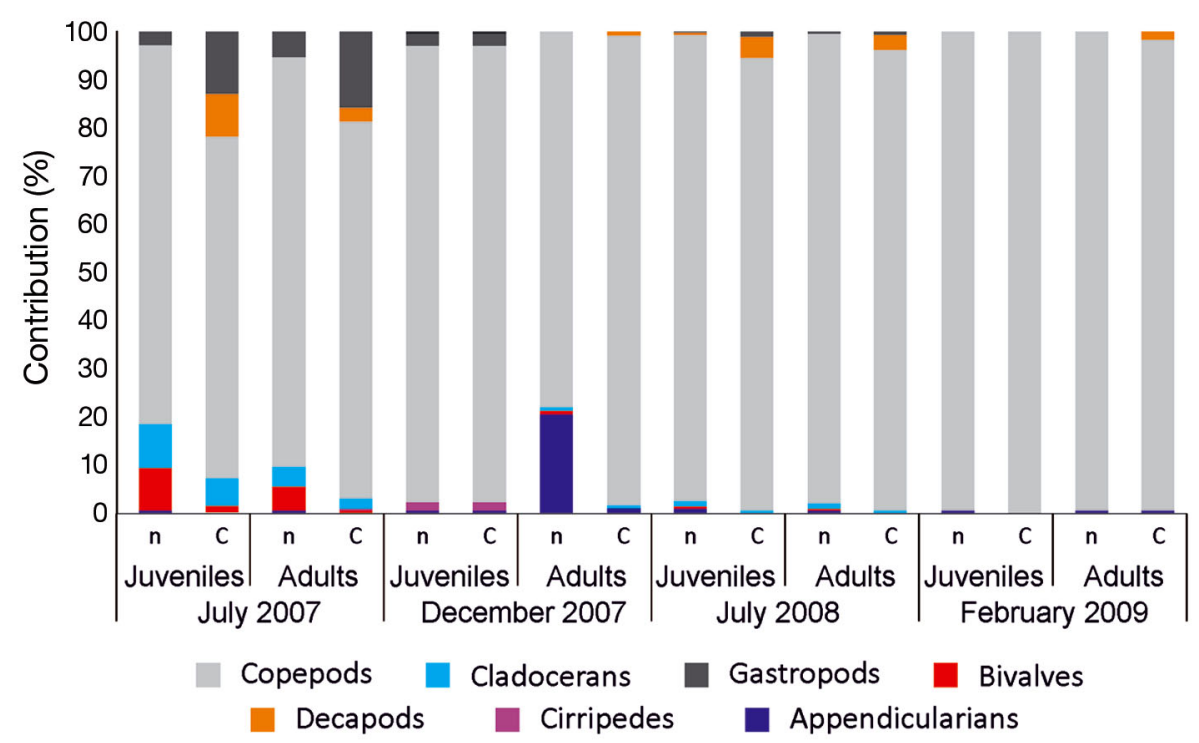

Fig. 4. Engraulis encrasicolus. Percentages of prey categories per fish stomach in terms of numbers $(\% n)$ and dietary carbon $(\% \mathrm{C})$ content the interaction of Ontogenetic Stage $\times$ SP $(\% n$ : pseudo- $F=1.47, \mathrm{p}=0.183$ ) nor the factor Ontogenetic Stage ( $\% \mathrm{n}$ : pseudo- $F=1.42, \mathrm{p}=0.223$ ) were significant. On the contrary, the differences between sampling periods were highly significant ( $\% \mathrm{n}$ : pseudo- $F=36.88, \mathrm{p}=0.0001)$. Finally, no significant differences were detected when comparing the size-frequency distributions of prey between juveniles and adults in each SP (Table S3 in the Supplement).
In terms of prey numbers, the taxa that contributed most to the differences in diet between July 2007 and 2008 were Oncaea spp. and Temora spp. The appendicularians and Calanus spp. were the prey that differentiated the diet composition between December 2007 and February 2009 (Table S4 in the Supplement). In terms of carbon content, the differences between July 2007 and 2008 were due to Temora stylifera and the larvae of decapods (e.g. Crab zoea) and gastropods. Differences between

Table 3. Ivlev's selectivity index for mesozooplankton taxa with $>1 \%$ numerical contribution to anchovy Engraulis encrasicolus diet. Ivlev's index ranges from -1 to +1 ; negative values indicate avoidance, and positive values indicate selection for a prey. Values close to zero indicate neutral selectivity. Values $\leq-0.5$ or $\geq 0.5$ in bold

\begin{tabular}{|c|c|c|c|c|c|c|c|c|}
\hline \multirow{2}{*}{ Taxon } & \multicolumn{2}{|c|}{ _ July 2007} & \multicolumn{2}{|c|}{ _ December 2007} & \multicolumn{2}{|c|}{ _ July 2008} & \multicolumn{2}{|c|}{ February 2009} \\
\hline & Juveniles & Adults & Juveniles & Adults & Juveniles & Adults & Juveniles & Adults \\
\hline Acartia clausi & 0.997 & 0.848 & 0.499 & 0.090 & 0.208 & 0.247 & 0 & 0 \\
\hline Appendicularians & 0 & 0 & 0.586 & 0.721 & 0 & 0 & 0 & 0 \\
\hline Calanus spp. & 0 & 0 & 0.089 & -0.296 & 0 & 0 & 0 & 0 \\
\hline Candacia spp. & 0 & 0 & 0.832 & 0.739 & 0 & 0 & 0 & 0 \\
\hline Centropages spp. & -0.445 & -0.086 & 0.725 & 0.743 & 0 & 0 & 0.396 & 0.397 \\
\hline Cirripeds & 0 & 0 & 0.258 & 0 & 0 & 0 & 0 & 0 \\
\hline Copepod nauplii & 0.829 & 0 & -0.105 & 0 & 0 & 0 & 0 & 0 \\
\hline Corycaeidae & 0.597 & 0.651 & 0.377 & -0.104 & 0.802 & 0.659 & 0.579 & 0.751 \\
\hline Euterpina acutifrons & 0.925 & 0.961 & 0.554 & 0 & 0.974 & 0.970 & 0 & 0 \\
\hline Evadne spinifera & 0 & 0 & -0.172 & 0 & 0 & 0 & 0 & 0 \\
\hline Gastropods & 0.644 & 0.894 & 0 & 0 & 0 & 0 & 0 & 0 \\
\hline Harpacticoids & 0.762 & 0 & 0 & 0 & 0 & 0 & 0 & 0 \\
\hline Bivalves & 0.980 & 0.964 & 0.885 & 0 & 0 & 0 & 0 & 0 \\
\hline Microsetella rosea & 0 & 0 & 0 & 0 & 0.950 & 0.958 & 0 & 0 \\
\hline Oithona spp. & 0.814 & 0.134 & 0 & 0 & 0.456 & 0.43 & 0 & 0 \\
\hline Oncaea spp. & 0.815 & 0.862 & 0.550 & 0.771 & 0.966 & 0.968 & 0.837 & 0.851 \\
\hline Clauso-Paracalanidae & -0.883 & -0.912 & -0.637 & -0.695 & -0.715 & -0.715 & -0.459 & -0.663 \\
\hline Penilia avirostris & -0.563 & -0.767 & 0 & 0 & -0.924 & -0.920 & 0 & 0 \\
\hline Podon spp. & 0.723 & 0.329 & 0 & 0 & 0 & 0 & 0 & 0 \\
\hline Pteropods & 0 & 0.778 & 0 & 0 & 0 & 0 & 0 & 0 \\
\hline Temora stylifera & 0.414 & 0.006 & -0.436 & -0.493 & 0.626 & 0.623 & 0 & 0 \\
\hline
\end{tabular}


Table 4. Engraulis encrasicolus and Sardina pilchardus. Degree of diet overlap based on Schoener's index between juvenile (J) and adult (A) anchovy in each sampling period, and between juvenile or adult anchovy and sardine in each sampling period. Schoener's index calculated based on numeric content $\left(\% \mathrm{n}, \mathrm{S}_{\mathrm{n}}\right)$ and carbon content $\left(\% \mathrm{C}, \mathrm{S}_{\mathrm{C}}\right)$ contribution of prey in the diet. Index values range from 0 to 1 , with 0 indicating no overlap and 1 complete overlap. Data for sardine from Nikolioudakis et al. (2012)

\begin{tabular}{|llccc|}
\hline Species & $\begin{array}{l}\text { Sampling } \\
\text { period }\end{array}$ & $\begin{array}{c}\text { Ontogenetic } \\
\text { stage }\end{array}$ & $\mathrm{S}_{\mathrm{n}}$ & $\mathrm{S}_{\mathrm{C}}$ \\
\hline Anchovy & Jul 2007 & J vs. A & 0.607 & 0.543 \\
& Dec 2007 & J vs. A & 0.801 & 0.825 \\
& Jul 2008 & J vs. A & 0.957 & 0.976 \\
& Feb 2009 & J vs. A & 0.947 & 0.958 \\
Anchovy & Jul 2007 & J & 0.596 & 0.680 \\
vs. & Jul 2008 & J & 0.704 & 0.642 \\
sardine & Jul 2007 & A & 0.142 & 0.499 \\
& Dec 2007 & A & 0.083 & 0.860 \\
& Jul 2008 & A & 0.219 & 0.592 \\
& Feb 2009 & A & 0.072 & 0.818 \\
\hline
\end{tabular}

December 2007 and February 2009 were mainly due to different contributions of large-sized copepods (Centropages spp., Calanus spp. and Candacia spp.) (Table S4). SIMPER analyses with Season (summer or winter) as a separating factor revealed that differences in anchovy diet between stratification and mixing periods resulted from the copepods Centropages spp. and T. stylifera in terms of both $\% \mathrm{n}$ and $\% \mathrm{C}$ (Table S4). In terms of \%C, decapod larvae (e.g. crab zoea), Acartia clausi and gastropod larvae also contributed highly to seasonal dietary differences (Table S4).

The multivariate analyses based on \%n showed a clear differentiation in diet composition between adult anchovies and sardines in both stratified and mixing periods (Fig. 5A). The interaction term Season $\times$ Species was highly significant (PERMANOVA, $\% \mathrm{n}$ : pseudo- $F=11.60, \mathrm{p}=0.0001)$. Additionally, Schoener's index indicated very low overlap in the diet of the 2 species in each SP (Table 4). When prey $\% \mathrm{C}$ was taken into consideration, the seasonal differentiation of the diet was not as clear, and a third group was defined at the $50 \%$ similarity level comprised of anchovy samples from both winter and summer (Fig. 5B). The PERMANOVA test showed that only the effects of Season and Species were significant $\left(\% \mathrm{C}\right.$ : pseudo- $F_{\text {season }}=38.24, \mathrm{p}=0.0001$, pseudo- $\left.F_{\text {species }}=16.16, \mathrm{p}=0.0001\right)$. Schoener's index (\% C data) suggested high dietary overlap for the 2 species in each winter period $\left(\mathrm{S}_{\mathrm{C} \text { W07 }}=0.860, \mathrm{~S}_{\mathrm{C} \text { w09 }}=\right.$ 0.818 ) and moderate overlap in each summer period $\left(\mathrm{S}_{\mathrm{C} \mathrm{S07}}=0.499, \mathrm{~S}_{\mathrm{C} \mathrm{S08}}=0.592\right)$.
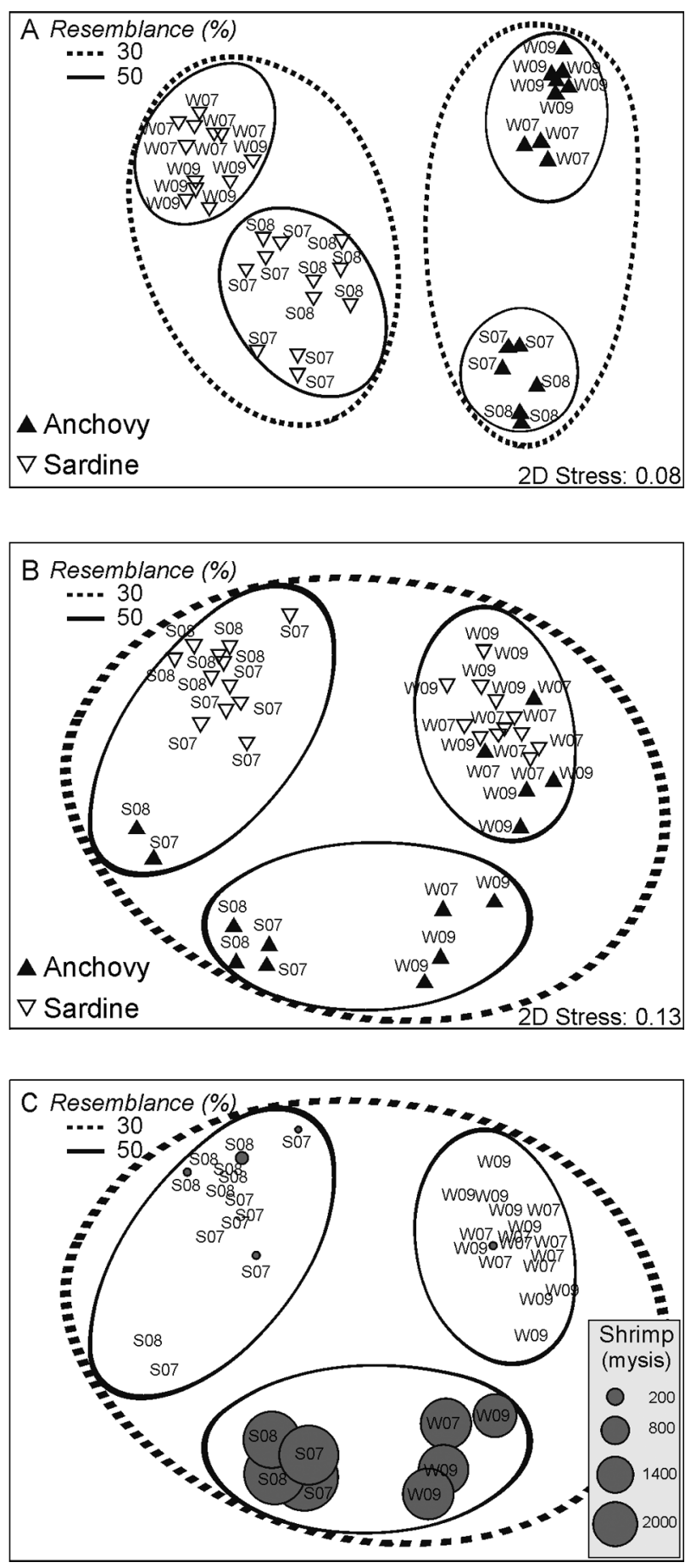

Fig. 5. Engraulis encrasicolus and Sardina pilchardus. Multidimensional scaling ordination plot of all the adult samples used to analyze anchovy and sardine diets based on (A) \%n and (B) \% C. Groups defined by the respective cluster analyses (at $30 \%$ and $50 \%$ resemblance levels) are also indicated. (C) Same as (B), with bubbles representing the carbon contribution (in pg C) of shrimp (mysis) in fish stomachs. S07 = July 2007, W07 $=$ December 2007, S08 = July 2008 and W09 = February 2009. Data for sardine from Nikolioudakis et al. (2012) 
In numerical terms, the different diet compositions of the 2 species were mainly due to the high concentration of phytoplankton cells in sardine stomachs (Table S5 in the Supplement). However, in terms of carbon, the contribution of phytoplankton cells was trivial (Nikolioudakis et al. 2012). The taxa that differentiated the diet of the 2 species in each SP and/or Season were decapod larvae (mainly shrimp mysid), followed by large-sized (i.e. rich in carbon) copepods (Table S6 in the Supplement). In fact, the definition of the additional anchovy cluster in Fig. 5B was due to the increased contribution of shrimp (Fig. 5C), the prey with the highest carbon content.

\section{Prey sizes}

In all SPs, lengths of anchovy prey were mainly 401 to $800 \mu \mathrm{m}$ and 1201 to $1400 \mu \mathrm{m}$ (Fig. 6, Table S3). The 401 to $800 \mu \mathrm{m}$ size classes was comprised of small and medium-sized copepods, cladocerans, cirriped nauplii and gastropods, whereas the 1201 to $1400 \mu \mathrm{m}$ class contained larger copepods and decapod larvae (Table S3). In terms of carbon, the 1201 to $1400 \mu \mathrm{m}$ class contributed considerably in all SPs, but in summer the 401 to $800 \mu \mathrm{m}$ class was also important (Fig. 6, Table S3).

When only copepods and cladocerans were used to construct the size frequency distributions in stomachs and in the field (Fig. 7), our results showed that anchovy derived the bulk of its dietary carbon from larger copepods, with the exception of July 2007 when smaller prey also contributed to a large degree (Fig. 7). The consumption of larger copepods (e.g. Centropages spp., Calanus spp., Eucalanus spp., Candacia spp.; Table S1) was particularly high during winter, and the overlap between available prey sizes in the field and those consumed by anchovies was lower (Fig. 7). In contrast, the increased contribution of the 401 to $800 \mu \mathrm{m}$ range in summer was due to the ingestion of small-sized copepods (e.g. Oithona spp. and Oncaea spp.) and cladocerans (Table S1). The higher consumption of larger prey when they were more abundant in the field, i.e. during winter (see Nikolioudakis et al. 2012, their Fig. S1 in the Supplement at www.int-res.com/ articles/suppl/m453p173_supp.pdf), was corroborated by the significant linear relationship between the mean size of copepods and cladocerans in anchovy stomachs and their respective size in the field: $\log _{10}\left(\right.$ size $\left._{\text {diet }}\right)=3.76 \times \log _{10}\left(\right.$ size $\left._{\text {field }}\right)-7.82 ; n=4, r^{2}=$ $0.984, \mathrm{p}=0.016$.
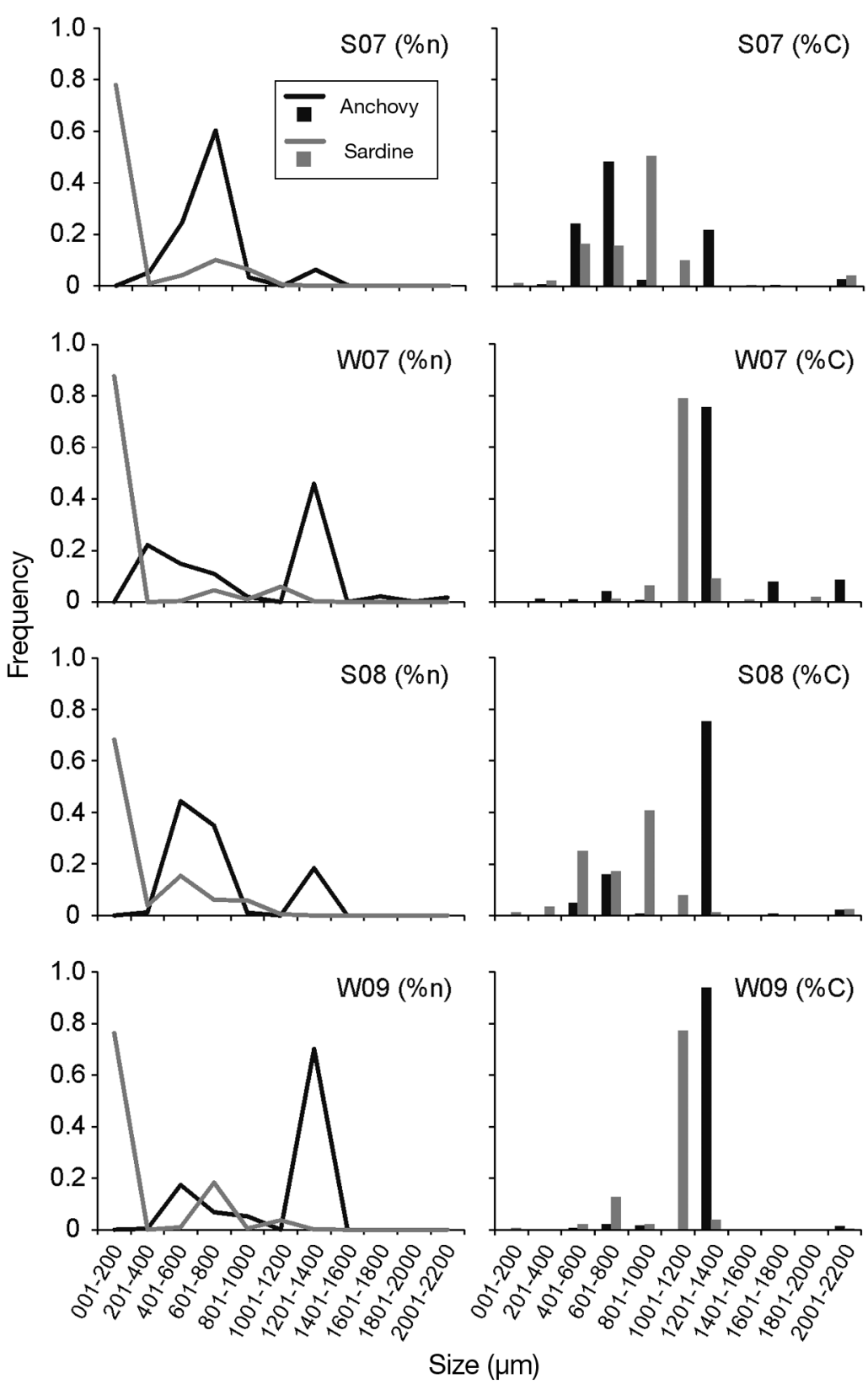

Fig. 6. Engraulis encrasicolus and Sardina pilchardus. Size-frequency distribution of all prey taxa found in the stomachs of adult anchovies and adult sardines in terms of numbers (lines) and dietary carbon (bars). S07: July 2007; W07: December 2007; S08: July 2008; W09: February 2009. Data for sardine from (Nikolioudakis et al. 2012) 

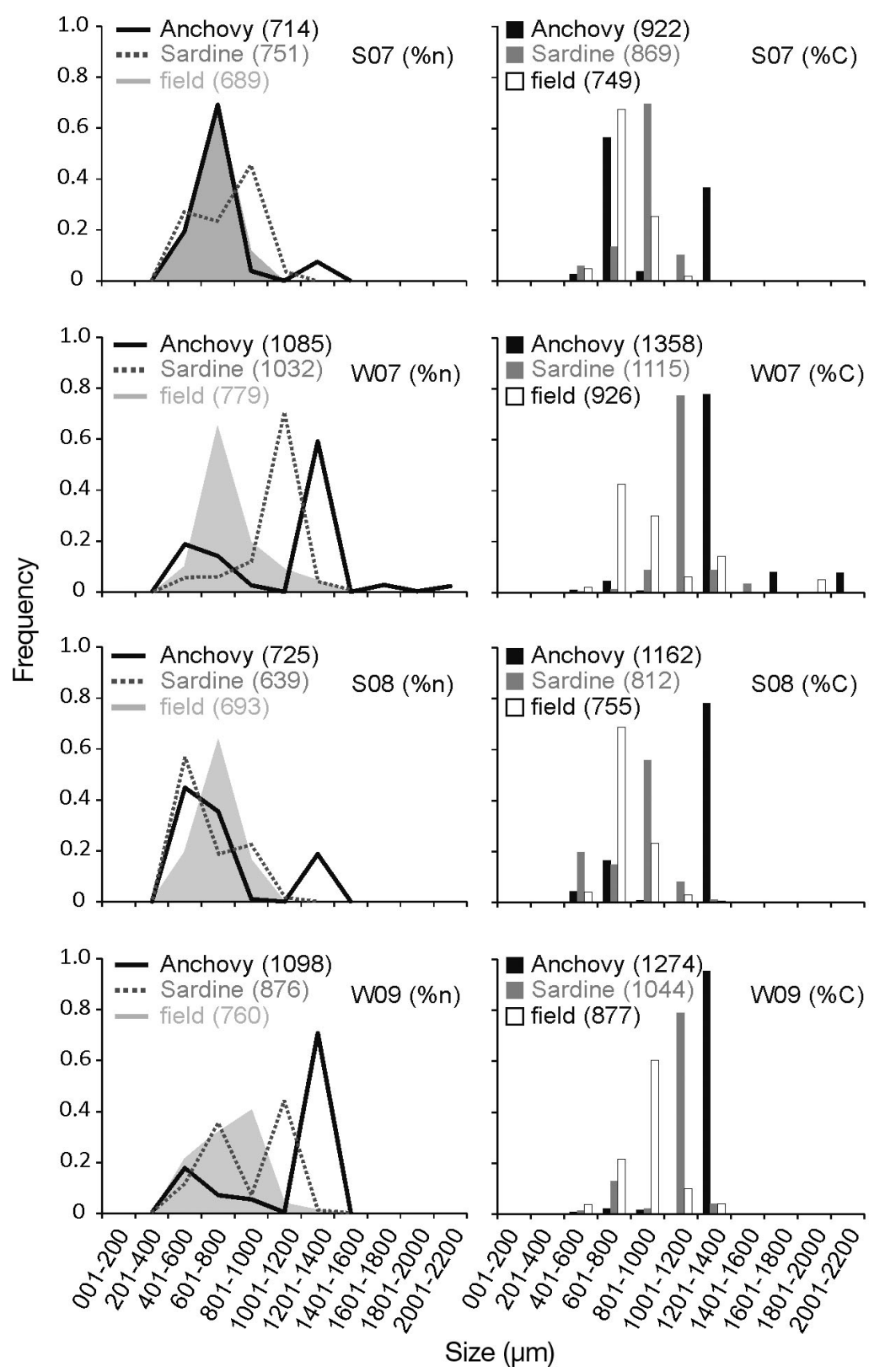

Fig. 7. Engraulis encrasicolus and Sardina pilchardus. Size-frequency distribution of copepods and cladocerans in the stomachs and the field in terms of numbers (lines) and dietary carbon (bars) for anchovy and sardine adults. Weighted mean sizes in the diet and the field (in $\mu \mathrm{m}$ ) are shown in parentheses. S07: July 2007; W07: December 2007; S08: July 2008; W09: February 2009. Data for sardine and field from Nikolioudakis et al. (2012)

The comparison of prey-size frequency distributions between anchovy and sardine (Fig. 6) demonstrated that anchovy captured larger prey. Anchovy did not target organisms $<200 \mu \mathrm{m}$ (i.e. phytoplankton, microzooplankton), whereas prey in sardine stomachs never exceeded $<1600 \mu \mathrm{m}$. However, the left side of the anchovy prey-size distribution (numerical frequencies) overlapped with that of sar- dine (Fig. 6). In terms of carbon, the prey-size distributions exhibited higher overlap, mainly in the 400 to $800 \mu \mathrm{m}$ range during the stratification periods S07 and S08. Trophic segregation in terms of prey size was more pronounced during the mixing periods W07 and W09.

When only copepod and cladoceran prey was considered, the greater overlap in prey-size frequency distributions between the 2 species and the respective size frequency distributions of copepods and cladocerans in the field was also revealed (Fig. 7). Both anchovy and sardine seemed to aim for the largest copepods that they were capable of consuming in each SP (Fig. 7), with the largest prey available in the field ingested more frequently by anchovy.

\section{DISCUSSION}

\section{Feeding periodicity and daily ration}

Anchovies in temperate, non-upwelling areas forage primarily during daytime, exhibiting maximum stomach contents at dusk, with a rapid decrease thereafter (Mediterranean: Tudela \& Palomera 1995, Plounevez \& Champalbert 2000, Borme et al. 2009; Bay of Biscay: Plounevez \& Champalbert 1999; Kuroshio Current region: van der Lingen 2009 and references therein). In contrast, in upwelling systems, anchovy feeding peaks at dusk or night (e.g. Espinoza \& Bertrand 2008), with intense nocturnal feeding focused mainly on larger zooplankton occasionally taking place (e.g. Benguela: James 1987). In the Mediterranean, nocturnal feeding is considered sporadic (mainly focused on large prey) and does not alter the characteristic diurnal feeding pattern in early summer (Tudela \& Palomera 1995) or autumn (Borme et al. 2009). However, in our study area, the feeding intensity during daytime was substantially lower relative to nighttime during the mixing periods (December and February), when anchovy significantly increased foraging activity from sunset to midnight. 
Anchovies and sardines exhibited common diel feeding patterns in our study area irrespective of sampling period, as evidenced by the strong correlations of their stomach-content weights at each sampling time (Fig. 2). The same diel feeding patterns were also observed between adults and juveniles, implying that feeding periodicity is established early in ontogeny. Synchronicity in diel foraging intensity has also been reported for Engraulis japonicus and Sardina melanostictus in the Northwest Pacific, with both species being daytime feeders (van der Lingen et al. 2009). Conversely, in upwelling areas (e.g. Benguela, California, Humboldt), the anchovy-sardine pairs exhibit different diel activities, i.e. sardines feed continuously throughout the diel cycle while anchovies present strong feeding periodicity, primarily feeding during daylight (van der Lingen et al. 2009). Such regional differences in interspecific patterns of diel foraging activity might be associated with the diel vertical migration (DVM) of fish (e.g. James 1987, Giannoulaki et al. 1999, Tsagarakis et al. 2012) in relation to the vertical distribution of their preferred prey (Bertrand et al. 2010).

In an attempt to explain the different diel foraging pattern of sardine between summer and winter, Nikolioudakis et al. (2011) proposed that the high temperatures experienced by fish in surface layers during summer (July 2007: $\sim 26^{\circ} \mathrm{C}$, July 2008: $\sim 28^{\circ} \mathrm{C}$ ) reduce the ability of the cardio-respiratory system to deliver sufficient amounts of oxygen to tissues (Jobling 1997), causing the suppression of foraging activity at night. Anchovies (Tsagarakis et al. 2012) and sardines (Giannoulaki et al. 1999) have similar DVM behaviors during summer in the North Aegean Sea, being distributed above the thermocline at night, when both species exhibited reduced feeding intensity. On the contrary, in winter the water column was homogenized, with substantially lower temperatures (December 2007: $\sim 14^{\circ} \mathrm{C}$, February 2009: $\sim 11^{\circ} \mathrm{C}$; Nikolioudakis et al. 2011), which suggests that temperature did not prevent fish from extending their foraging activity into the early night.

In contrast to other areas where anchovy egg cannibalism is quite common (e.g. Engraulis encrasicolus, formerly E. capensis; Valdés et al. 1987), such behavior is virtually absent in the Mediterranean Sea (Tudela \& Palomera 1997, Bacha \& Amara 2009, Borme et al. 2009, Costalago et al. 2012). The spatial segregation of feeding and spawning grounds has been suggested as the reason for the lack of anchovy egg cannibalism in this basin (Tudela \& Palomera 1997, Bacha \& Amara 2009). Furthermore, in summer anchovy spawning occurs from 22:00 $\mathrm{h}$ to $02: 00 \mathrm{~h}$ local time (Somarakis et al. 2012), i.e. when both species dramatically decrease their feeding activity. This reduces the probability of cannibalism and intraguild predation on anchovy eggs. We also found no egg cannibalism for sardine in winter, when this species reproduces in the Aegean Sea (Ganias et al. 2007). Although the spawning behavior of the Mediterranean sardine is poorly known, it has been demonstrated in the Atlantic (Ganias et al. 2011) that spawning individuals of this species move offshore to spawn. Such behavior could explain the lack of cannibalism or intra-guild predation on sardine eggs at the coastal site where sampling for this study took place.

Juvenile anchovies always consumed more food per unit mass compared to adults. To our knowledge, this is the first time that consumption estimates for juvenile European anchovy have been provided in the literature, even though such information is very important for the development of fish bioenergetics models (e.g. Politikos et al. 2011). Adult consumption estimates in summer were similar to those reported for the western Mediterranean during the spawning period (Catalan Sea: 3.9\% TW; Tudela \& Palomera 1995, Gulf of Lions: 4 \% TW; Plounevez \& Champalbert 2000). Winter estimates were substantially lower, but variations in daily ration between seasons were explained by the more general dependence of consumption on fish size and per capita food availability (Fig. 3).

In most current predator-prey and food web models, the per capita predation rate, or predator functional response, is assumed to be a function of prey density alone ('prey-dependent' functional response). In recently developed small pelagic fish bioenergetics models, plankton consumption has been modeled as a function of prey density alone, without accounting for any predator density effects (e.g. Politikos et al. 2011). However, Arditi \& Ginzburg (1989) argue that, more basically the dependence of the predator-prey functional response should be on the ratio of prey density to predator density, thus introducing the 'ratio-dependent' functional response model. Nikolioudakis et al. (2011) demonstrated that the daily consumption of sardine is strongly related to the per capita food availability (the $B_{R}$ ratio), and a similar relationship was defined for anchovy in the present study. Moreover, we also show (Fig. 3) that the density-dependence of DR is valid, irrespective of the 'species' factor, which suggests similar consumption levels for anchovy and sardine that are primarily controlled by fish weight and intraspecific competition. At the spatial scale of the 
present study, the abundance of one species in relation to available mesozooplankton did not seem to affect the consumption rate of the other species, and vice versa.

\section{Diet}

Juvenile and adult anchovies exhibited high dietary overlap with no significant differences in prey sizes or diet composition. Borme et al. (2009) also found that anchovy diet was similar between juveniles and adults in the Adriatic Sea, whereas in Algeria, Bacha \& Amara (2009) found an ontogenetic shift from copepods towards decapods and amphipods as fish increased in size. In the Gulf of Lions, Costalago et al. (2012) reported differences in the diet between juveniles and adults in summer, but not in autumn and winter. Finally, in upwelling areas (e.g. Benguela) where large phytoplankton cells can play a substantial role in anchovy diet under certain conditions, the finer structure of the feeding apparatus of adult fish leads to the differentiation of their diet from that of juveniles, which are more zooplanktivorous (James 1987). The high dietary overlap between juveniles and adults found in the North Aegean for anchovy has also been demonstrated for sardine (Nikolioudakis et al. 2012). Although adult sardines retained large numbers of phytoplankton, when dietary carbon was considered, both juveniles and adults were shown to rely on the same energy source, i.e. copepods (Nikolioudakis et al. 2012).

The main source of dietary carbon for anchovy in the North Aegean Sea was mesozooplankton and, more specifically, copepods. Previous dietary studies also agree on the high importance of copepods in anchovy diet throughout its range (Benguela: James 1987; Bay of Biscay: Plounevez \& Champalbert 1999; North Sea and Baltic Sea: Schaber et al. 2010, Raab et al. 2011; Catalan Sea and Gulf of Lions: Tudela \& Palomera 1997, Plounevez \& Champalbert 2000; Adriatic Sea: Borme et al. 2009; Algeria: Bacha \& Amara 2009; Black Sea: Bulgakova 1993). Apart from copepods, other mesozooplankton groups complemented the diet of anchovy (appendicularians, gastropods, bivalves and decapods), revealing the dietary plasticity of the species (highlighted in other studies as well, e.g. decapods: Bacha \& Amara 2009; bivalves: Borme et al. 2009; appendicularians: Capitanio et al. 2005, Costalago et al. 2012). The broadening of the trophic niche of anchovy was more pronounced in summer, suggesting that when large copepods were less available, anchovy turned to other mesozooplankton resources to meet their energetic demands.

The selective feeding on or avoidance of specific prey found in this study have also been demonstrated for anchovy in other areas of the Mediterranean and the North and Baltic Seas (e.g. Tudela \& Palomera 1997, Borme et al. 2009, Raab et al. 2011, Costalago et al. 2012). Selective preference or avoidance of specific prey by fish could be explained in terms of copepod swimming behavior or density of specific prey in the environment causing the switching between filter- or particulate feeding modes (Nikolioudakis et al. 2012). For example, the high selectivity shown here for the copepods Microsetella rosea or Oncaea spp. has also been reported in other cases (Tudela \& Palomera 1997, Borme et al. 2009, Costalago et al. 2012) and is likely associated with the patchiness of these species' distributions. Similarly, the avoidance (negative Ivlev selectivities) for the abundant Clauso-Paracalanidae group could be the result of their rapid and continuous swimming behavior (Mazzocchi \& Paffenhöfer 1999), making them 'inaccessible' to fish (Nikolioudakis et al. 2012). Although energetically costly for anchovy (James \& Probyn 1989), filter-feeding is employed when patchy distributions of small copepods are encountered, whereas particulate feeding is used for capturing larger prey (James \& Findlay 1989, Tudela \& Palomera 1997). At all times, the balance between the costs and benefits of foraging on particular prey (i.e. whether or not the energetic demands for capture and handling exceed the profits of consumption) seems to be the governing factor for selecting or avoiding this prey, as well as for switching between filter- and particulate feeding.

The seasonal differences in the diet of anchovy were largely related to the structure and function of the pelagic food web in the study area (described in detail in Nikolioudakis et al. 2012). In brief, the conditions imposed by the thermal stratification in July (i.e. low nutrient supply leading to an enhanced microbial-loop mediated food web) favored the prevalence of small copepods (Nikolioudakis et al. 2012). These copepods, although efficiently exploited by anchovy during that period (as evidenced by their contribution to dietary carbon), were probably insufficient to satisfy the energetic demands of the fish. This could explain the broadening of the trophic niche in summer, as mentioned earlier for anchovy and also shown for sardine (Nikolioudakis et al. 2012). However, it is likely that a linear planktonic food web (diatoms $\rightarrow$ copepods $\rightarrow$ fish) was more prominent during the mixing periods, since the 
abundant large copepods (e.g. Centropages spp., Calanus spp.) could benefit from the high concentrations of phytoplankton cells (mainly diatoms). Accordingly, anchovy responded by foraging upon the energy-rich large copepods, as the positive relationship between the mean size of copepods and cladocerans in the field and in the stomachs suggested.

Anchovies and sardines are considered trophically distinct, exhibiting size-based resource partitioning, with anchovies relying mostly on large prey, and sardines more efficiently exploiting smaller zooplankton sizes (van der Lingen et al. 2009 and references therein). Although phytoplankton has been found to contribute significantly to the diet of the 2 species in certain areas/conditions (e.g. James 1987, Garrido et al. 2008), it is well established that the bulk of their dietary carbon is of zooplanktonic origin (e.g. James 1987, van der Lingen et al. 2006, Espinoza \& Bertrand 2008, Garrido et al. 2008, Espinoza et al. 2009, Nikolioudakis et al. 2012). The main differentiation in the diet of the 2 species in the North Aegean Sea resulted from the high numbers of phytoplankton cells ingested by adult sardines. The ability of sardines (Sardinops sagax, Sardina pilchardus) to retain smaller particles than anchovies is widely recognized (van der Lingen et al. 2006, Garrido et al. 2007) and attributed to differences in the structure of the feeding apparatus which becomes finer in sardines with increasing size (van der Lingen et al. 2009).

When the carbon contribution of prey was considered, anchovy and sardine exhibited medium to high dietary overlap (depending on season). Differences were mainly due to the large carbon contribution of bigger prey (e.g. decapod larvae) that was more frequently found in anchovy stomachs. However, both anchovy and sardine seemed to satisfy most of their energetic demands by exploiting the larger copepods that they were capable of catching. This is in contrast with the strong and clear size-based resource partitioning described in upwelling systems, where anchovy more efficiently exploits larger zooplankton, while sardine relies mainly on smaller zooplankton gained at a lower energetic cost (Benguela Current: van der Lingen et al. 2006; California Current: van der Lingen et al. 2009; and Humboldt Current: Espinoza et al. 2009), although sardine is able to forage on large zooplankton, as has been shown in the northern Humboldt current system (Espinoza et al. 2009). Other studies from the Kuroshio Current and the Baltic Sea also demonstrate high dietary overlap for local SPF pairs (Kuroshio: Sardina melanostictus - Engraulis japonicus, Li et al. 1992; Baltic: Clupea harengus_-Sprattus sprattus, Möllmann et al.
2004), implying that the strong size-based resource partitioning observed in the highly productive upwelling systems is not that clearly displayed by SPF pairs in non-upwelling areas.

In conclusion, the direct comparison of anchovy and sardine diets in the present study revealed that the trophic ecology of the 2 species was similar in the North Aegean Sea. They shared common feeding periodicity patterns that differed between stratification and mixing periods, with daily ration being dependent on fish size and per capita food availability. The main inter-specific differences in the diets were the high numerical contribution of phytoplankton in adult sardine stomach contents (poor in energy) and the more frequent ingestion of large prey by anchovy, especially decapod larvae (rich in energy). When the carbon content of prey was considered, interspecific similarity in diet was higher, dominated by copepods, but larger copepods were again more efficiently exploited by anchovy. Sardine relied on slightly smaller copepods than anchovy but not the smallest available in the field. The interspecific differences found in this study are most likely associated with anatomical (structure of the feeding apparatus), physiological (metabolic costs of feeding mode employed in relation to availability and size of prey) and behavioral differences (switching between filter- and particulate feeding).

Acknowledgements. The present study was part of the European Project SARDONE (Improving assessment and management of small pelagic species in the Mediterranean, FP6-44294). The authors thank A. Machias, M. Giannoulaki, K. Tsagarakis, E. Schismenou, and the captain and crew of the RV 'Philia', for their invaluable help during sampling, as well as the technical staff of HCMR who assisted in this study. We also thank the 3 anonymous reviewers who helped improve our manuscript.

\section{LITERATURE CITED}

Alheit J, Roy C, Kifani S (2009) Decadal-scale variability in populations. In: Checkley D, Alheit J, Oozeki Y, Roy C (eds) Climate change and small pelagic fish. Cambridge University Press, Cambridge, p 64-87

Anderson M, Gorley R, Clarke K (2008) PERMANOVA+ for PRIMER: guide to software and statistical methods. PRIMER-E, Plymouth, MA

Arditi R, Ginzburg L (1989) Coupling in predator-prey dynamics: ratio-dependence. J Theor Biol 139:311-326

Bacha M, Amara R (2009) Spatial, temporal and ontogenetic variation in diet of anchovy (Engraulis encrasicolus) on the Algerian coast (SW Mediterranean). Estuar Coast Shelf Sci 85:257-264

> Bertrand A, Ballón M, Chaigneau A (2010) Acoustic observation of living organisms reveals the upper limit of the oxygen minimum zone. PLoS ONE 5:e10330 
Borme D, Tirelli V, Brandt SB, Fonda Umani S, Arneri E (2009) Diet of Engraulis encrasicolus in the northern Adriatic Sea (Mediterranean): ontogenetic changes and feeding selectivity. Mar Ecol Prog Ser 392:193-209

Bulgakova Y (1993) Daily feeding dynamics of the Black Sea anchovy, Engraulis encrasicholus. J Ichthyol 33:78-88

Capitanio F, Pájaro M, Esnal G (2005) Appendicularians: an important food supply for the Argentine anchovy Engraulis anchoita in coastal waters. J Appl Ichthyol 21: 414-419

Checkley D, Ayon P, Baumgartner T, Bernal M and others (2009) Habitats. In: Checkley D, Alheit J, Oozeki Y, Roy $\mathrm{C}$ (eds) Climate change and small pelagic fish. Cambridge University Press, Cambridge, p 12-44

Clarke K, Warwick R (1994) Change in marine communities: an approach to statistical analysis and interpretation. Plymouth Marine Laboratory, Plymouth

> Costalago D, Navarro J, Álvarez-Calleja I, Palomera I (2012) Ontogenetic and seasonal changes in the feeding habits and trophic levels of two small pelagic fish species. Mar Ecol Prog Ser 460:169-181

> Cury P, Bakun A, Crawford R, Jarre A, Quinones R, Shannon L, Verheye H (2000) Small pelagics in upwelling systems: patterns of interaction and structural changes in 'wasp-waist' ecosystems. ICES J Mar Sci 57:603-618

Eggers D (1979) Comments on some recent methods for estimating food consumption by fish. J Fish Res Board Can 36:1018-1019

Elliott J, Persson L (1978) The estimation of daily rates of food consumption for fish. J Anim Ecol 47:977-991

Espinoza P, Bertrand A (2008) Revisiting Peruvian anchovy (Engraulis ringens) trophodynamics provides a new vision of the Humboldt Current system. Prog Oceanogr 79:215-227

Espinoza P, Bertrand A, van der Lingen C, Garrido S, Rojas de Mendiola B (2009) Diet of sardine (Sardinops sagax) in the northern Humboldt Current system and comparison with the diets of clupeoids in this and other eastern boundary upwelling systems. Prog Oceanogr 83: 242-250

Field DB, Baumgartner TR, Ferreira V, Gutiérrez D, LozanoMontes H, Salvatteci R, Soutar A (2009) Variability from scales in marine sediments and other historical records. In: Checkley D, Alheit J, Oozeki Y, Roy C (eds) Climate change and small pelagic fish. Cambridge University Press, Cambridge, p 45-63

Ganias K, Somarakis S, Koutsikopoulos C, Machias A (2007) Factors affecting the spawning period of sardine in two highly oligotrophic seas. Mar Biol 151:1559-1569

Ganias K, Nunes C, Vavalidis T, Rakka M, Stratoudakis Y (2011) Estimating oocyte growth rate and its potential relationship to spawning frequency in teleosts with indeterminate fecundity. Mar Coast Fish 3:119-126

Garrido S, Marçalo A, Zwolinski J, van der Lingen CD (2007) Laboratory investigations on the effect of prey size and concentration on the feeding behaviour of Sardina pilchardus. Mar Ecol Prog Ser 330:189-199

Garrido S, Ben-Hamadou R, Oliveira PB, Cunha ME, Chícharo MA, van der Lingen CD (2008) Diet and feeding intensity of sardine Sardina pilchardus: correlation with satellite-derived chlorophyll data. Mar Ecol Prog Ser 354: 245-256

Giannoulaki M, Machias A, Tsimenides N (1999) Ambient luminance and vertical migration of the sardine Sardina pilchardus. Mar Ecol Prog Ser 178:29-38
Gutiérrez D, Sifeddine A, Field D, Ortlieb L and others (2009) Rapid reorganization in ocean biogeochemistry off Peru towards the end of the Little Ice Age. Biogeosciences 6:835-848

Héroux D, Magnan P (1996) In situ determination of food daily ration in fish: review and field evaluation. Environ Biol Fishes 46:61-74

Ivlev V (1961) Experimental ecology of the feeding of fishes. Yale University Press, New Haven, CT

> James A (1987) Feeding ecology, diet and field-based studies on feeding selectivity of the Cape anchovy Engraulis capensis Gilchrist. S Afr J Mar Sci 5:673-692

> James AG, Findlay KP (1989) Effect of particle size and concentration on feeding behaviour, selectivity and rates of food ingestion by the Cape anchovy Engraulis capensis. Mar Ecol Prog Ser 50:275-294

$>$ James A, Probyn T (1989) The relationship between respiration rate, swimming speed and feeding behaviour in the cape anchovy Engraulis capensis Gilchris. J Exp Mar Biol Ecol 131:81-100

Jobling M (1997) Temperature and growth: modulation of growth rate via temperature change. In: Wood CM, McDonald DG (eds) Global warming: implications for freshwater and marine fish. Cambridge University Press, Cambridge, p 225-254

Li X, Kawasaki T, Honda H (1992) The niches of the Far Eastern sardine and Japanese anchovy. Asian Fish Sci 5: 315-326

Mazzocchi M, Paffenhöfer G (1999) Swimming and feeding behaviour of the planktonic copepod Clausocalanus furcatus. J Plankton Res 21:1501-1518

Möllmann C, Kornilovs G, Fetter M, Köster F (2004) Feeding ecology of central Baltic Sea herring and sprat. J Fish Biol 65:1563-1581

Nikolioudakis N, Palomera I, Machias A, Somarakis S (2011) Diel feeding intensity and daily ration of the sardine Sardina pilchardus. Mar Ecol Prog Ser 437:215-228

> Nikolioudakis N, Isari S, Pitta P, Somarakis S (2012) Diet of sardine Sardina pilchardus: an 'end-to-end' field study. Mar Ecol Prog Ser 453:173-188

Pikitch EK, Rountos KJ, Essington TE, Santora C and others (2014) The global contribution of forage fish to marine fisheries and ecosystems. Fish Fish 15:43-64

Plounevez S, Champalbert G (1999) Feeding behaviour and trophic environment of Engraulis encrasicolus (L.) in the Bay of Biscay. Estuar Coast Shelf Sci 49:177-191

Plounevez S, Champalbert G (2000) Diet, feeding behaviour and trophic activity of the anchovy (Engraulis encrasicolus L.) in the Gulf of Lions (Mediterranean Sea). Oceanol Acta 23:175-192

> Politikos DV, Triantafyllou G, Petihakis G, Tsiaras K, Somarakis S, Ito SI, Megrey BA (2011) Application of a bioenergetics growth model for European anchovy (Engraulis encrasicolus) linked with a lower trophic level ecosystem model. Hydrobiologia 670:141-163

Raab K, Nagelkerke L, Boerée C, Rijnsdorp A, Temming A, Dickey-Collas M (2011) Anchovy Engraulis encrasicolus diet in the North and Baltic Seas. J Sea Res 65:131-140

Schaber M, Petereit C, Paulsen M (2010) Diet composition and feeding of European anchovy Engraulis encrasicolus in Kiel Bight, western Baltic Sea. J Fish Biol 76: 1856-1862

Schoener T (1970) Nonsynchronous spatial overlap of lizards in patchy habitats. Ecology 51:408-418

Skjoldal HR, Wiebe PH, Postel L, Knutsen T, Kaartvedt S, 
Sameoto DD (2013) Intercomparison of zooplankton (net) sampling systems: Results from the ICES/GLOBEC seagoing workshop. Prog Oceanogr 108:1-42

Somarakis S, Tsianis DE, Machias A, Stergiou KI (2006) An overview of biological data related to anchovy and sardine stocks in Greek waters. In: Palomares MLD, Stergiou KI, Pauly D (eds) Fishes in databases and ecosystems. Fisheries Centre Research Reports 14(4), Fisheries Centre, University of British Columbia, Vancouver, p 56-64

Somarakis S, Schismenou E, Siapatis A, Giannoulaki M, Kallianiotis A, Machias A (2012) High variability in the daily egg production method parameters of an eastern Mediterranean anchovy stock: influence of environmental factors, fish condition and population. Fish Res $117-$ 118:12-21

Tsagarakis K, Giannoulaki M, Somarakis S, Machias A (2012) Variability in positional, energetic and morphometric descriptors of European anchovy Engraulis encrasicolus schools related to patterns of diurnal vertical migration. Mar Ecol Prog Ser 446:243-258

Tudela S, Palomera I (1995) Diel feeding intensity and daily

Editorial responsibility: Konstantinos Stergiou, Thessaloniki, Greece ration in the anchovy Engraulis encrasicolus in the northwest Mediterranean Sea during the spawning period. Mar Ecol Prog Ser 129:55-61

Tudela S, Palomera I (1997) Trophic ecology of the European anchovy Engraulis encrasicolus in the Catalan Sea (northwest Mediterranean). Mar Ecol Prog Ser 160: 121-134

> Valdés ES, Shelton PA, Armstrong MJ, Field JG (1987) Cannibalism in South African anchovy: egg mortality and egg consumption rates. In: Payne AIL, Gulland JA, Brink $\mathrm{KH}$ (eds) The Benguela and comparable ecosystems. S Afr J Mar Sci 5:613-622

> van der Lingen C, Hutchings L, Field J (2006) Comparative trophodynamics of anchovy Engraulis encrasicolus and sardine Sardinops sagax in the southern Benguela: are species alternations between small pelagic fish trophodynamically mediated? Afr J Mar Sci 28:465-477

van der Lingen $C D$, Bertrand $A$, Bode $A$, Brodeur $R$ and others (2009) Trophic dynamics. In: Checkley D, Alheit J, Oozeki Y, Roy C (eds) Climate change and small pelagic fish. Cambridge University Press, Cambridge, p 112-157

Submitted: June 13, 2013; Accepted: October 13, 2013

Proofs received from author(s): February 17, 2014 